\title{
Salendang Dance Choreography Developing the Arts of Tourism Performance in Mandeh Area
}

\author{
$\operatorname{Nerosti}^{1, *}$ \\ ${ }^{1}$ Lecturer of Sendratasik Department, Faculty of Language and Art, Universitas Negeri Padang, Padang, Indonesia \\ *Corresponding author. Email: nerosti@fbs.unp.ac.id
}

\begin{abstract}
This article is the result of research (2020) which aims to develop the choreography of Salendang Dance with the concept of tourism performance art. The method used by Research \& Development (R\&D) by Borg and Gall is by conducting preliminary research, planning, development to be carried out, testing, revising works and improving choreography. Maquet's theory named the form of tourism packaging as art by metamorphosis or art that has undergone a change of form, or art of acculturation, or pseudo traditional art, or tourist art. Art that has not been packaged is called art by destination. The Wimsatt diagram states that tourist performances are a balance between traditional arts and the tourism industry, with criteria: imitation of the original, short and compact, full of variations from the original event, and if sold at a low price. Choreography development refers to the theory of Hawkins which processes from: (1) Sensory Data, (2). Feeling, (3). Imaging, (4). Transforming, and (5). The results of the research, the choreography development of the Salendang Dance has been carried out. Based on the results of previous research, there are 8 motives of motion. Each motive of motion is variedly developed into the form of a phrase by processing energy, space and time, thus producing an orderly and varied form of choreography, as a symbol of the lineage of Puti-puti Tarusan. Dance packaging is in accordance with the criteria for tourism performing arts including motion development, floor design, music, costumes and make-up, and shawl properties. All new styled worth showing off to tourists.
\end{abstract}

Keywords: Salendang dance, tourism performing arts, choreography and Puti- puti's descent

\section{INTRODUCTION}

Salendang dance is a traditional dance that has developed since the Tarusan kingdom which joined the autonomous village federation was still victorious [1]. With the entry into force of the handover of the autonomous nagari federation to the 17th century Company which was witnessed by Sri Sultan Achmad Sjah Jang Dipertuan in Minangkabau for the sake of politics and the smooth running of trade [1], over time the power of small kingdoms decreased. Even so, the Tarusan Kingdom still survived up to 9 descendants. Listening to this history, the Salendang Dance which once developed among the descendants of King Tarusan needs to be reconstructed. Reconstruction has been carried out in previous research [2], entitled Reconstruction of the Dampieng Salendang Dance by taking inventory of historical aspects, functions, found 8 motives of motion in their original form based on story illustrations from Puteri Normaya and Puteri Darna [2].

Previous research on the dance was given the name Dampieng Salendang based on an agreement with Yusnimar, daughter-in-law of Puteri Noermaya as the leader of the Pucuak Rabuang Studio in Tarusan. The reason for giving the name Dampieng Salendang is because the dance is accompanied by the Dampiang art, namely dendang. However, when I met Princess Darna in January 2019, she objected to the dance being given the name Dampieng Salendang, the request is enough for the name Salendang dance only, so that there are two forms of art, namely Salendang and Dampieng Dance. Based on Princess Darna's recommendation, in the second year (2020) I came up with the title "Developing Choreography of Salendang Dance with a Concept of Tourism Performing Arts in the Mandeh Region". The research aims to produce choreography products for the Salendang Dance with the concept of art tourism including motion, floor design, music and clothing

The presence of a new form of performing arts with commercial or professional aims in a country has never escaped the country's economic growth. If economic growth is good, it means that a portion of the average income per capita of the population can be set aside for recreation, then the development of commercial performing arts will also be good [3]. This research is in sync with government programs that define West Sumatra as one of the main tourist destinations in Indonesia [4]. Mandeh, which is known as a hidden paradise, is the location where the Salendang Dance develops.

Now it is starting to prove that the Mandeh area, which is located in Koto XI Tarusan District, although not yet as advanced as Bali tourism has been, Mandeh is the "Pilot Project for Indonesian tourism destinations since 2015". Even on 25 November 2017 Mandeh won first place in the Most Popular Hidden Heaven category at Anugerah Pesona Indonesia (API) II for Maritime Tourism [2]. Various marine tourism activities are held, even the Mandeh Festival which also holds various traditional arts from each village. The festival has been scheduled for every 2 years. The development of Mandeh tourism is like 
a gold field for the community, especially supported by the construction of infrastructure in the form of a road from Bungus Teluk Kabung Padang to the Mandeh area. [5]. Although many traditional arts have become extinct, due to the expertise of the tourism industry, this almost extinct performing arts can come back to life [3]. Tourism performing arts that need to be short, dense, and interesting and for the packaging of performing arts for tourism purposes $\mathrm{J}$. namely pseudo traditional art, which is known as tourist art. Art that has not been packaged is called art by destination, which is art that is used by the community itself [6], uses the Wimsatt diagram of a group of immigrants, namely tourists who present a certain art style, at the same time the local community will maintain traditional art. The art performed in the tourism industry is a combination of tradition and tourism [6].

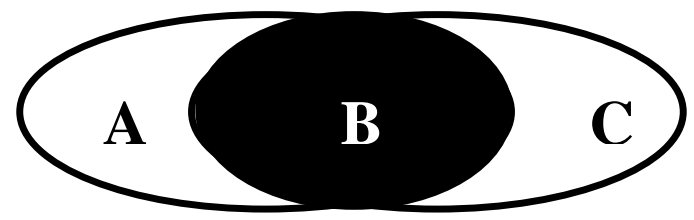
A: Traditional Performance
B: Tourist show
C: Tourism Industry

In the development of choreography theory is used, that the formation of dance starts from the sensory senses of a choreographer that spreads in the body [7], then proceeds as follows:

1. Feeling (appreciate) To appreciate the senses captured from life events or findings that are considered attractive become important sensations in the body.

2. Images (imagining) The senses that are captured become imaginary responses and create new imaginations that develop and appear alternately quickly, like a kaleidoscope.

3. Transforming (embodying) The discovery of integral aesthetic qualities related to the imagination (which is still abstract) which is then concretized by devoting all thoughts to be manifested into the desired motion ideas.

4. Forming (giving form) The movements are formed naturally based on the science of choreography and dance aesthetic elements. These phases form the structure of the Salendang dance.

Hawkins' theory is also used by Silalahi.

(1) Exploration: a) determining the title / theme / topic of creation through stories and conceptions; b) Thinking, imagining, feeling, responding and interpreting the chosen theme. (2) Improvisation: a) experiments to select, distinguish, consider, harmonize, and certain contrasts; b) determine the integration and unity of the various experiments that have been carried out. (3) Formation: a) determining the form of the creation by combining symbols resulting from various experiments that have been carried out; b) determine unity with other parameters, such as accompaniment movement, dress and color; and c) giving weight to art (complexity, simplicity and intensity) and cultural weight [8].

\section{METHOD}

The research method used was Research \& Development (R\&D) developed by Borg and Gall (2003) with 10 steps of R\&D research: (1). Research and Information colletion (conducting preliminary research), which researchers have done in 2018 (2). Planning (doing planning), (3) Developing Preliminary form of Product (developing initial products) with the instructors, (4) Preliminary Field Testing (initial field trials), (5) Main Product Revision (Performing operational product revisions), (6) Main Field Testing (main field trials). (7) Operational product revision (making operational product revisions, (8) Operational Field Testing (operational field trials), (9) Final Product Revision (Making final product revisions), and (10) Disemination and Implementation (Deploying and implementing) [9], this has not been done because this research is only a choreography development stage. Hopefully it can be done next year.

\section{RESULTS AND DISCUSSION}

\subsection{History of the Salendang Dance}

Salendang dance was originally developed among the Putiputi descendants of the Tarusan Kingdom in the XVIII century, who were only danced by women to welcome the King's Son or have the title Sutan before siding in the aisle. The origin of Puti-puti's descendants in Tarusan can be seen in Ranji at Puteri Noermaya's house, which originated from (1) King Tarusan named Sutan Djahja, the title of Sutan Perhimpunan Alam. At first he became the Chief Head of Nagari Sungai Pinang. In March 23, 1876 was appointed Head of the Barrel in Tarusan. Swear on Painan. Quit with a request for a pension. On 19 January 1912, he was awarded the Silver One Buntang. Here on June 1, 1881 to 1951. (2) King Tarusan St Kadir Tuangku Radja Hitam. At first the Kingdom sat in the hamlet then moved to the Talang River. At that time the company came to Malaboh to die because of Tuak. Then Radja returned to the hamlet and died buried in Mandah Hill. (3) Radja Tarusan St Satih Titled Radjo Hitam Tuangku Nan Goreng. Swarmed with the company in Padang. Sitting kingdom in Pondok from 1708 until 1722. This was when Radja Sungai Pinang died and buried in Mandah Hill. (4) Radja Tarusan, the name of St Dajat, was named Bagindo St Besar, sat in the kingdom in Nanggalo from 1738 to 1756. Ninik brought the marriage with the woman Setia Wanara Salido to Nanggalo Tarusan. The king died buried in Bairah Limau Puruik in Nanggalo. Then in 1956 he was transferred (Dokar) nearby from 1776-1796. (8) King Tarusan Sutan Madat title Tuangku Rajo Hasan. Swore an oath with Kompenidi Padang on March 28, 1724 to 26 
November 1854. Made a long house in Nanggalo Tarusan. In 1954 JC Eigger came to Tarusan and buried opposite the Pondok. He moved to bury there. (9) King Tarusan St Ismael, the title Bagindo St Besar, began as King in Sungai Pinang on January 9, 1855, swore an oath with the Company in Padang Rank Regent. Stopped by request on February 18, 1876, then died [2].

From Ranji, who was obtained from Puteri Noermaya, it was proven that in Tarusan there were indeed descendants of the King's Princess who were also known as Puti-puti's descendants, which we can now meet in Tarusan, namely Princess Reno Intan and Princess Noermaya. Therefore, the existence of the Selendang dance in Tarusan has the truth that it is one of the traditional dances that should be preserved.

\subsection{Salendang Dance Choreography Development}

In the process of developing choreography at the Pucuak Rabung Tarusan studio, data collection is carried out in showing the form of motion to the dancers, these movements are:

1) Kuriek Kundi: Nan kuriek iyolah kundi, nan merah iyolah sago, nan baiek iyolah budi,nan endah iyolah baso.Its most valuable meaning in social life is associating with good manners and courtesy.

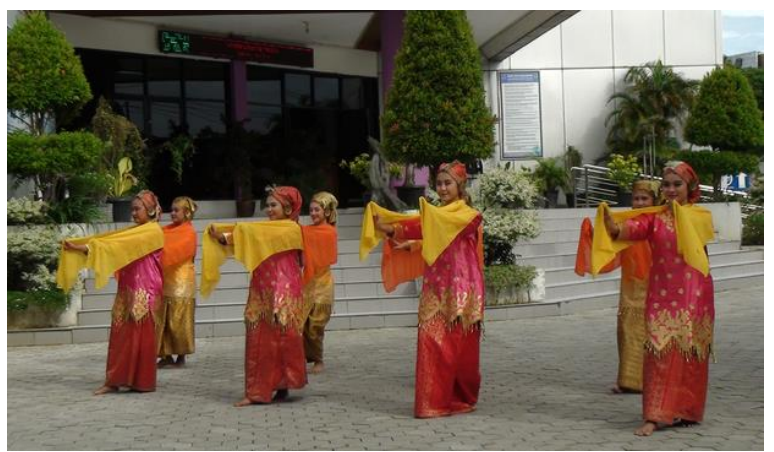

Figure. 1

This movement in the 2018 study was only in the form of poses, which is holding the scarf by covering the shoulders. Then developed by jogging diagonally as shown in Figure 1. Then both hands are swung to the left side and also done to the right then rotate.

2) Limpapeh, this motion mimics a flying butterfly. It can be interpreted based on Minangkabau petitih quotes: 'Limpapeh rumah nan gadang, umbun puruak pegangan kunci'. Minangkabau women are a solid pillar on a household and a country, and the key to a country's good and bad. This movement aimed at women is interpreted as advice for the bride and groom. Limpapeh which is a small, fragile white butterfly. The wings are very easily damaged even though they are exposed to the wind, the wings can be torn. Therefore it is westernized to women who must be good at taking care of themselves. Zahir refinement of language should be accompanied by refined intellect, because women are household servants who will educate children as the descendants of kings and princesses. Women also have to be trustworthy because they are inheritance holders in the rumah gadang.

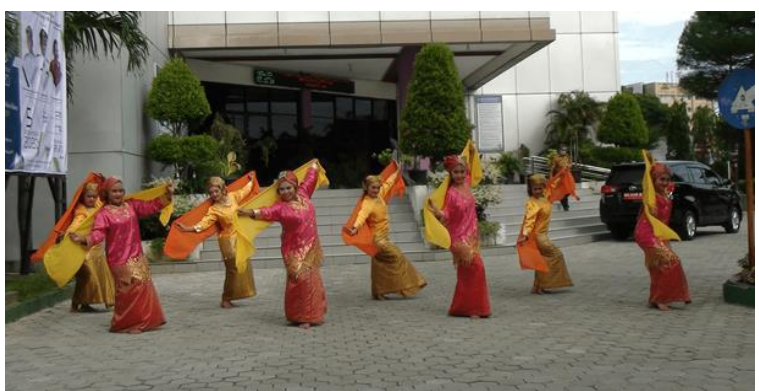

Figure 2

3) Balabeh is firmness in preserving inheritance in the form of heirloom and non-physical assets, namely customs that must always be preserved. Barih balabeh nan ko kini, nan warih bajawek juo, kaganti gujalo tubuah, paukua bayang-bayang maso. The meaning of customary teachings if explored will be able to measure the progress of the times in the field of human morals. Therefore, in this motion the scarf is always stretched firmly. This motion is done while walking, diagonally to the right and to the left. Every step that is carried out always uses a double step or child steps. So that the impression is moving up and down.

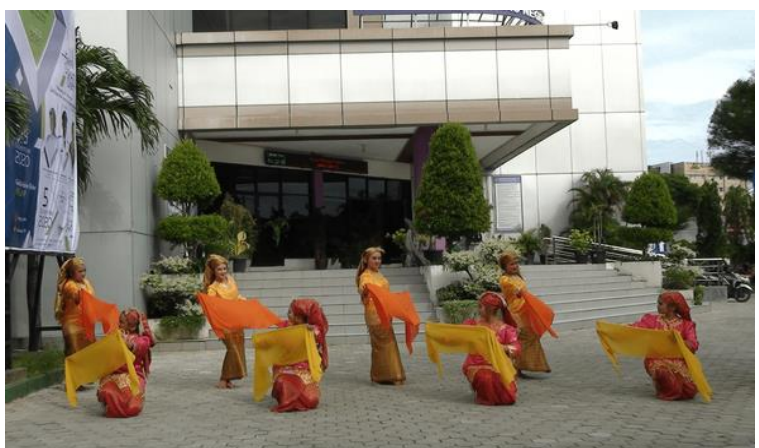

Figure 3

4) Paga, this movement can be interpreted as " "Kuek nan dari paga basi, kokoh nan dari paga tembok" means that the strongest fence is the fence of something with a good mind.

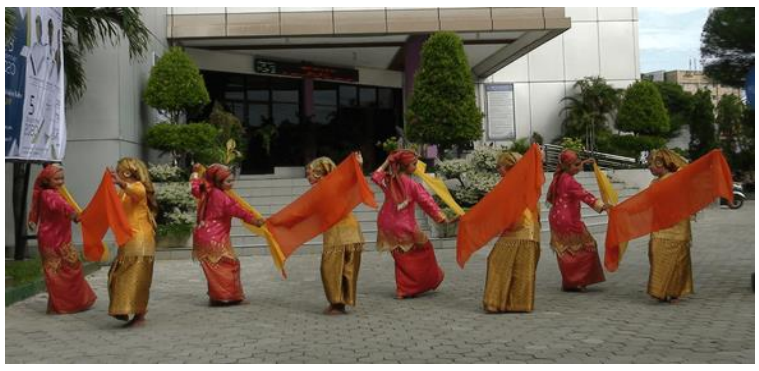

Figure 4 
This movement is done in place, sometimes forward and sometimes backward.

5) Anta, this movement is the opening move of the Salendang dance, which is performed at the beginning of the dance when the groom has arrived at the bride's house to carry out the marriage contract. The anta gesture serves to lead the groom to the aisle, but in a dance performance when the groom arrives at the bride's house, a dampiang is sung. There are 8 dancers

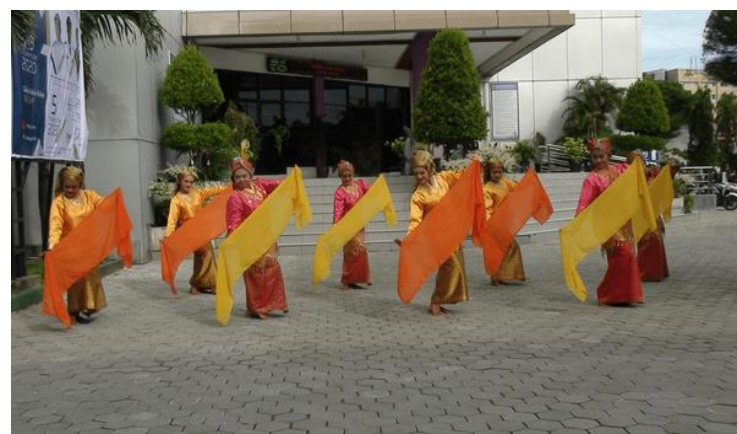

Figure 5

6) Warih, this movement is likened to the adage: "Warih samo dijawek, pusako samo ditolong". The meaning of inheritance is a moral responsibility for the lineage who received it to pass on to the next generation. Heirlooms must be helped together to maintain them. The legacy will continue to be passed on to the next generation.

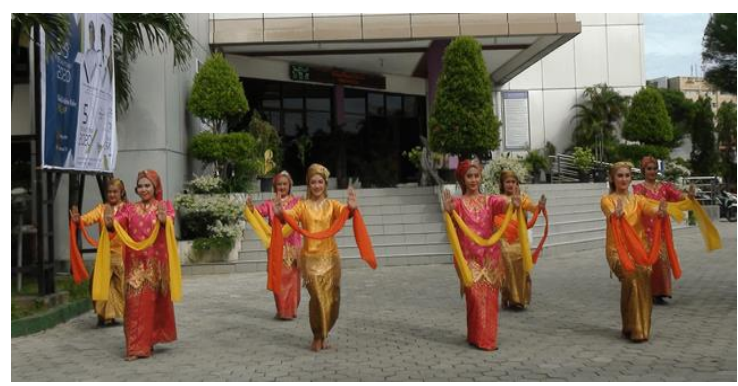

Figure 6

7) Anjuang, this movement is likened to a high place. Nak tinggi kato dianjuang, naiekkan budi nan haluih baso jo basi" . If you want to be respected by others in society, keep your mind and use small talk or speak nicely.

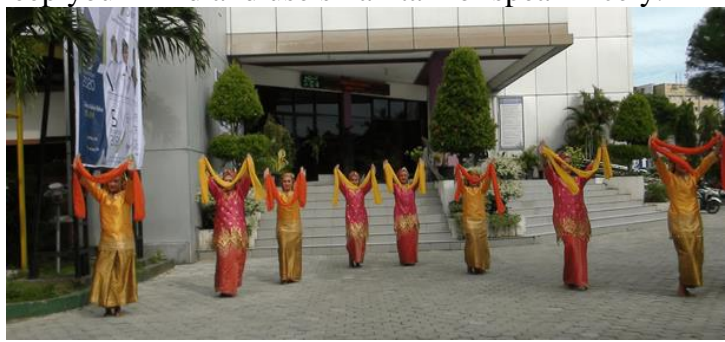

Figure 7
8) Ikek, this movement is interpreted as the wife's duty to tie the husband's heart, through good service. All the husband's needs can be fulfilled by the wife. It was raised in a saying: "Padi diikek jo daunnyo, batang ditungkek jo dahannyo". The wisdom that is used by someone in leading a nephew's child, to) Ikek this movement is interpreted as the wife's duty to tie the husband's heart, through good service. All the husband's needs can be fulfilled by the wife. It was raised in a saying: "Rice is scraped jo leavesnyo, stems are bent jo dahannyo". The wisdom that is used by someone in leading a nephew, to pay for it, is found for an effort. looking for a business.

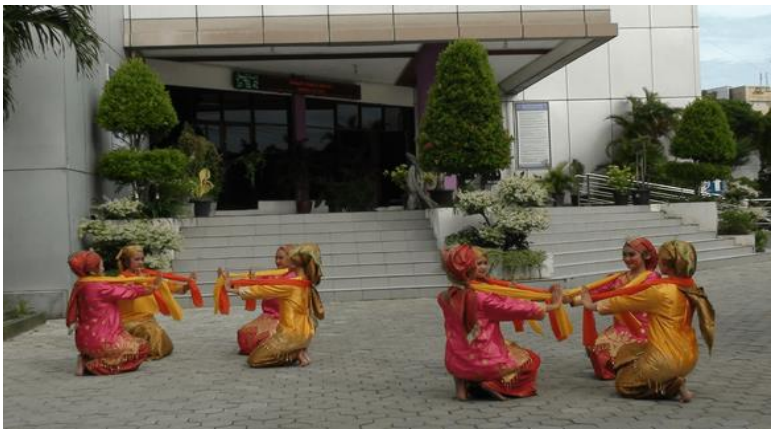

Figure 8

The meaning of the Salendang Dance described above refers to the activities and traditions that apply in the implementation of marriage, such as bakuruang or kuriek kundi, which is the deification of a woman who becomes a wife. Ikek movement as a symbol in the household of how a wife is clever to tie her husband's heart. Likewise with the movement of warih, paga, a guard against the heirloom that must be helped to be saved. The gestures of the husband and wife that should be praised are all typical symbols of cultural products that are abstract from the daily habits of the local community which contain educational values. By interpreting the symbols and cultural phenomena presented in the Salendang dance, an abstract meaning can be revealed, which is built through social agreement as an expression of dance expressions that have the characteristics of Tarusan which have symbolic value [10].

From the dance work above, the development of the choreographic elements has been carried out according to the criteria of the art of tourism, namely: short or dense, varied, original imitation, excluded from the ritual, and of course if tourists pay according to their ability (but this has not been tested) because it is still in the development stage of new research choreography. The main development is movement because motion is an important part as a medium for dance expression, movement can also give shape and can measure the values of the beauty of dance [11].

These developments include dancers, floor design, music and make-up and clothing. The dancer aspect is no longer 
parents like in the heyday of the Tarusan kingdom. In terms of movement, it differs when compared to preliminary research [2], where the Salendang Dance movement is only a short motif or pose. For this reason, in developing choreography in the aspects of energy, space and time [12], it is the main goal in the Salendang Dance. In addition, to produce good choreography work is also supported by the ability of the dancer's body which is ready to use. In this case, it takes sufficient time and continuous exploration so that the body can do more choreography. The arrangement of the dancer's body requires perseverance in practicing so that the dancer's body is more comfortable in dancing [13].

Other poses such as fencing (paga), maambek by opening the scarf hanging down in front of the body, rotating the shawl over the head with both hands holding both ends and making the body fence shawl.

These shapes are arranged into various forms of motion phrases which are developed into 3-4 motives such as the kuriek kundi (bakuruang) movement, which is holding the scarf by covering the shoulders. Then developed by jogging in a diagonal direction as in Figure 2. Then swing both hands to the left side and also done to the right and then rotating. The floor pattern is also laid out in a variety of ways in the form of diagonals, large triangles, small triangles, rectangles, V, lined lines, sides and circles. The level game which is basically just standing, now there are those who sit at various levels, namely low, middle and high.

Since music is an integral part of most dance performances [14], the music that accompanies the Salendang Dance is illustrative, where it provides an atmosphere of dance movements, for example, slow dance movements accompanied by music with a calm character, loud / fast dance movements accompanied by loud and fast volume music, and the like. The music used is Dampieng accompanied by Talempong instruments [15]. The clothing uses yellow and pink brackets, with the model of the brackets and songket and takuluak clothes. Make up according to the needs of the show, namely beautiful makeup.

It is very different from the present condition, in the era of the kingdom where the performing arts functioned as a complement to the splendor of the Palace, the majestic performances held at the Palace with production funds borne by the king [3].

Although not all kingdoms in Indonesia in ancient times were large kingdoms that performed performing arts, even small kingdoms had performance arts including dance performed at certain events within the kingdom [2]. Along with the dissolution of the kingdom in Indonesia, the performing arts that developed within the kingdom automatically also did not succeed anymore, except in
Java, there are still some royal remains that are well preserved, while in many small kingdoms that have become extinct, melting into art that belongs to people. Even so, the art that resides is a legacy that must be preserved because it has an identity for the local community.

Every ethnic group in Indonesia wants to show their identity to a certain group of people. Identity that shows identity. If we want it to be easier to understand the differences that exist in each of these cultures, at least we must be able to identify the identity of each culture [16] Measuring identity in society can be through three forms, namely cultural identity, social identity, and personal identity [17]. The three forms of identity have been able to be expressed in the choreography of the Salendang Dance which is full of meaning.

With the development of the choreography of the Salendang Dance, it is hoped that it can become a new icon in Koto XI Tarusan District. Whatever form and function of dance that is reconstructed in this new form requires creativity and innovation. In creating dance in tourist performances, it is necessary to refer to traditional values [18]. Various traditional arts can be a source of inspiration for artists to create works of art according to market tastes. The development of dance can go hand in hand with the development of the tourism sector as an economic driver which has an economic impact on traditional artists in the Mandeh area. It is known that tourism is seen as a new economic movement that is expected to be able to raise the dignity of life and the welfare of the community [19].

The development of the Salendang Dance in addition to perpetuating traditional dance which can be used as an icon in Koto XI Tarusan District is also an effective, innovative conservation effort, accompanied by a spirit of mutual cooperation [20]. For this reason, this dance is developed into 8 dancers.

\section{CONCLUSIONS}

The development of the Salendang Dance has produced a dance product that is ready to be displayed to tourists in the Mandeh area (arts by methamorphosis). Choreography development occurs not only because of the preservation factor, but also because of professional factors which are marked by creativity. Satisfying tourists is a job that must be done, in order to improve the lives of the artists, orders always come. The motivation is money. Money is not just a symbolic expression of the aspects of life, but money is also a symbolic expression of other aspects of life such as social, cultural, political and religious [21].

\section{REFERENCES}

[1]. Mansoer. Sejarah Minangkabau. Jakarta: Bhatara, 1970. P.79 \& 101 
[2]. Nerosti. Dampieng Salendang Reconstruction in Building Millenial Generation Characters in the Field of Dance. In: Proceedings of the International Conference On Social Studies, Globalisation And Technology (ICSSGT 2019). Paris, France: Atlantis Press; p. 430-9. 2020.

[3]. R.M. Soedarsono, Seni Pertunjukan Indonesia di Era Globalisasi, Yogyakarta: Gadjah Mada University Press, 2010, p.226 \& 273.

[4]. D.Syafrani, S. Nora dan H.H Mira, "Partisipasi Masyarakat Lokal Dalam Mengembangakan Kawasan Wisata Keluarga (Studi Kasus Kawasan Wisata Pantai Purus Padang)", Jurnal Socius, Vol. 3, No.2, p. 122-139, February 2016.

[5]. Nerosti, "Tiga Gaya Tari Rantak Kudo Berpotensi Sebagai Sajian Pariwisata di Kawasan Mandeh dan Sekitarnya", Jurnal of Urban Society's, Vol 4, No 2, p. 89-102, October 2017.

[6]. Nerosti, "Tari Galombang di Minangkabau Menuju Industri Pariwisata", Journal of Urban Society's Art, Vol 13, No 2, p. 110-118, October 2013.

[7]. Hawkins, M. Alma, Moving From Within A New Method for Dance Making, Chicago: A Cappella Books, p.93, 1991.

[8]. Silalahi, L.Mega, "Pengembangan Kreativitas Dan Inovasi Penciptaan Karya Tari Dengan Metode Laboratorium Tari (Studi Kasus: Yayasan Seni Duta Santarina Batam)", Imaji 91 , Vol. 15, No. 2, p. 189 - 196, October 2017.

[9]. D.G. Meredith, P.G. Joyce and R.B. Walter, Educational Research and Introduction, Seventh Edition, Boston: Pearson Education Inc, 2003.

[10]. H.S. Amelia, H. Hartono, S.F. Totok, "The Symbolic Meaning of Kuadai Dance Performance in the Society of Semende Lampung", Jurnal CATHARSIS, Vol. 7, No.2, p. 150-159, Agustus 2018.

[11]. R. Taufik, E Erlinda, Rasmida, "Keberadaan tari Barabah Mandi Pada Masyarakatjorong Sungai Dadok Kenagarian Koto Tinggi Kecamatan Gunung Omeh Kabupaten Limapuluh Kota”, Melayu Arts And Performance Journal, Vol. 2, No. 1, p. 109-118, April 2019.

[12]. Martha, A. Sarassati, "Analisis Koreografi Tari Ketimang Burong Suku Sawang, Jurnal Joget, Vol.13, No.1, p.59-72, April 2019.
[13]. Sarjiwo, "Teknik Pengelolaan Tenaga: Kajian Koreografi Tunggal”, Resital, Vol. 11, No.1. p. 81-91, Juni 2010.

[14]. V. Maja and M. Sloboda, "Aesthetic Experience of Dance Performances", Psihologija. Vol. 45, No.1, p. 23-41, January 2012.

[15]. R. Budi, "Musik Iringan Drama Tari Pengembaraan Panji Inukertapati Bermisi Perdamaian dan Toleransi”, Resital, Vol. 20. No.1, p.13-23. April 2019.

[16]. M. Khoiruddin, K. Iwan, S. Agus, "Komunikasi Antar Budaya Dalam Perspektif Antropologi", Jurnal Manajemen Komunikasi, Vol. 1, No 1, p. 113-124, January 2016.

[17]. L. Alo, Makna Budaya Dalam Komunikasi Antar Budaya. Yogyakarta: Lembaga Kajian Islam dan Studi, 2003.

[18]. Nerosti, "Nilai-Nilai Kearifan Lokal Melalui Tari Galombang Gaya Sasaran: Studi Sasaran Sebagai Sarana Pendidikan Kultural”. Jurnal Dance \& Theatre Review, Vol. 2, No 1, p. 35-41, May 2019.

[19]. Yusrizal, Firdaus dan Y.A. Agung, "Dampak Sosial Budaya Pariwisata Masyarakat Majemuk Konflik Dan Integrasi Sosial Di Yogyakarta”, Jurnal Pariwisata, Vol.7, No.2, p. 95-105, September 2020.

[20]. M. Dwi, "EcoArt Through Various Approaches", Journal of Urban Society's Art, Vol.7, No.1, p. 21-29, April 2020.

[21]. Damsar. Sociology of Money, Padang: Andalas Universitas Press, 2006, p.34. 